\title{
YIELD PERFORMANCE OF FOUR ONION (ALLIUM CEPA L.) VARIETIES COMPARED WITH THE LOCAL VARIETY UNDER OPEN FIELD CONDITIONS AT ANSE BOILEAU, SEYCHELLES
}

\author{
M.O. Ijoyah ${ }^{1}$, H. Rakotomavo ${ }^{2}$ and M.V. Naiken ${ }^{3}$ \\ ${ }^{l}$ Department of Crop Production, University of Agriculture, P.O.Box 2373, Makurdi, \\ Benue State, Nigeria. \\ ${ }^{2.3}$ Vegetable Evaluation and Research Station, Anse Boileau, \\ P.O.Box 166, Mahe, Seychelles.
}

\begin{abstract}
A field experiment was conducted from April to September, 2005 and 2006 planting seasons at the Vegetable Evaluation and Research Station Farm located at Anse Boileau, Seychelles to evaluate the yield performance of four onion varieties, 'Onion Orient', 'Lucy 15205', 'CAL 606', and 'Red Creole-2' against the commonly grown variety 'Red Creole-1' under field conditions. The experiment consisted of five treatments laid out in a randomized complete block design with four replications. The results obtained showed that while variety 'Onion Orient' was the earliest to maturity, variety 'CAL 606' recorded the highest number of leaves, bulb size, biological bulb weight, economic bulb weight, dry bulb weight and best yield which were significantly $(P \leq 0.05)$ increased by $34.6 \%, 23.9 \%, 16.8 \%, 28.6 \%, 35.0 \%$ and $33.9 \%$ respectively in 2005 and $40.0 \%, 25.1 \%, 10.9$ $\%, 23.6 \%, 30.0 \%$ and $28.9 \%$ respectively in 2006 compared to those obtained from the regular variety 'Red Creole-1'. Similarly, the yield produced from varieties 'Onion Orient', 'Lucy 15205' and 'Red Creole-2' was significantly $(P \leq 0.05)$ increased by $9.8 \%, 15.1 \%$ and $28.8 \%$ respectively in 2005 and $5.36 \%, 6.19 \%$ and $25.6 \%$ respectively in 2006 compared to that obtained from 'Red Creole-1'. The yield of 'CAL 606' was the greatest, followed by 'Red Creole-2', 'Lucy 15205', 'Onion Orient' and 'Red Creole-1' respectively. The implication of this study, showed that variety 'CAL 606' performed best and could therefore be recommended as a potential replacement for the popular variety 'Red Creole-1' in Seychelles.
\end{abstract}

Keywords: onion varieties, yield

\section{INTRODUCTION}

Onion (Allium cepa L.) belongs to the family Liliaceae, an important group of crops worldwide (Best, 2000). The crop is a biennial herb of Central Asian origin and used in soups, salads and in canning industries (Tindal, 1983). The crop nutritional composition includes $2.0 \mathrm{~g}$ protein, $70 \mathrm{mg}$ calcium and $53 \mathrm{mg}$ phosphorus (Ado, 2001). It also contains the vitamins thiamine, riboflavin and niacin and is used for its medicinal value especially in the case of heart problems (Mettananda and Fordham, 2001). 
In Seychelles, onion is one of the priority vegetable crops and ranked second following tomato (Grubben, 1997). The variety 'Red Creole-1' is popularly grown by farmers, both for home use and source of income. Currently, it is the only variety available with an average yield of $22 \mathrm{t} / \mathrm{ha}$ (Ado, 2001). This was considered low especially when compared to the yield produced by other varieties grown elsewhere (Lao, 2002).

The study, was therefore aimed at evaluating the yield performance of four onion varieties against the commonly grown variety 'Red Creole-1' with the objective of identifying a variety with a higher yield performance to replace the low yielding local variety under field conditions.

\section{MATERIALS AND METHODS}

The experiment was conducted from April to September, 2005 and 2006 planting seasons, under field conditions at the Vegetable Evaluation and Research Station Farm, located at Anse Boileau, Seychelles. Four onion varieties, 'Onion Orient', 'Lucy 15205', 'CAL 606' and 'Red Reole-2' were evaluated alongside the popular variety 'Red Creole-1' for yield performance. Varieties 'Onion Orient', 'Lucy 15205' and 'CAL 606' originated from Denmark while varieties 'Red Creole-2' and 'Red Creole1' were from AVRDC-ARC, Africa Region, Tanzania. The varieties constituted the treatments.

Seeds of the varieties were sown in mid-April, in seed-boxes containing a sterilized substrate that comprised the mixture of top soil, welldecomposed poultry manure and coconut coir in the ratio 3:2:1. Three grams of seeds per variety were sown in each seed box in drills $1 \mathrm{~cm}$ deep and at a distance of $10 \mathrm{~cm}$ between drills. A thin layer of soil was placed over the seeds and covered with sterilized gunny bag to promote seed germination. The gunny bags were later removed when $85 \%$ of the seeds were observed to have germinated. This occurred in about five days after sowing the seeds in the nursery. Nursery care such as handpicking of weeds and hard- ening to produce sturdy seedlings were carried out. The seedlings were transplanted to the field experimental site at six weeks after nursery sowing.

The experimental area $\left(44.1 \mathrm{~m}^{2}\right)$, which consisted of sandy-loam soil was cleared, rotovated and divided into twenty plots. Each plot had an area of $1.2 \mathrm{~m}^{2}$. The plot consisted of six rows, in which 10 seedlings per row were transplanted at a spacing of $15 \mathrm{~cm} \times 10 \mathrm{~cm}$ giving a total plant population of 60 plants per plot $(500,000$ plants per hectare equivalent). The treatments were laid out in a randomized complete block design with four replications. Well-decomposed poultry manure was initially applied by broadcast at the rate of $360 \mathrm{~g}$ per plot, following the recommendation by Sunasee (2001). The manure was incorporated into the soil and watered immediately using the microsprinkler irrigation at the rate of 25 1 of water per plot per day, following the formula of Estico (2000).

The seedlings were shaded with coconut leaves immediately after transplanting to protect the seedlings against dehydration. The shade was removed 7 days after transplanting (DAT) when the seedlings were observed to be vigorous.

Two top dressings with mixed fertilizer NPK $(12: 12: 17)$ at the rate of $62.5: 62.5: 62.5 \mathrm{~kg} / \mathrm{ha}$ was applied, following the recommendation by Ripjma (1990) at four weeks after seedling transplant and repeated four weeks later. This translated into $20.8 \mathrm{~g}$ equivalent of the fertilizer applied to each plot. The fertilizer was applied about $7.5 \mathrm{~cm}$ away from the plant stand and placed at a depth of about $10 \mathrm{~cm}$, covered well with soil and watered immediately after each application. Weeding was done manually as the need arose. Harvesting was done in midSeptember when large portion of the leaves were dry.

Data taken included number of days to maturity from transplant, number of leaves per plant, bulb size (measured in $\mathrm{cm}^{2}$ by multiplying the length and width of bulb according to Moamogwe (2001), biological bulb weight (taken as the 
weight of bulb with leaves), economic bulb weight (taken as the weight of bulb without leaves), dry bulb weight (taken as the weight of bulb after curing) and yield ( $\mathrm{t} / \mathrm{ha}$ ). The data were subjected to Analysis of variance (ANOVA) while the Least Significant Difference (LSD) was used to separate treatment means, following the method of Obi (1990).

\section{RESULTS AND DISCUSSION}

In Table 1, the meteorological information of the trial site at Anse Boileau, Seychelles for the growth period from April to September, 2005 and 2006 is given. The average monthly temperature over the years ranged from $22.2^{0} \mathrm{C}$ to $30.2^{\circ} \mathrm{C}$. The average relative humidity ranged from $80.1 \%$ to $86.0 \%$. The maximum temperature and relative humidity range were considered high for the growth and development of onion. This view supports Khokar et al., (2002), who reported that maximum temperature above $30{ }^{\circ} \mathrm{C}$ and humidity (more than $80 \%$ ) enhance the reduction in onion yield. Generally, rainfall recorded was low during the crop growth period, while the month of June recorded the highest amount of rainfall and highest number of rainy days.
Total $\mathrm{N}$ value in the soil over the years was low $(0.03 \%$ and $0.06 \%)$. Similarly, the soil had a medium level of $\mathrm{P}(6.2 \mathrm{ppm}$ and $7.5 \mathrm{ppm})$ with a corresponding low level of $\mathrm{K}(0.06 \%$ and 0.09 $\%$ ) for the years 2005 and 2006 respectively. Relatively moderate amounts of exchangeable bases ( $\mathrm{Ca}$ and $\mathrm{Mg}$ ) were present in all the soil units. Over the years, organic matter was low $(1.2 \%$ and $1.4 \%)$ while the $\mathrm{pH}$ in water was near neutral (Table 2).

In Table 3, the yield performance of four onion varieties compared with the local variety 'Red Creole-1' under open field conditions at Anse Boileau, Seychelles during the 2005 and 2006 planting seasons is given. Variety 'Onion Orient' was the earliest (95.2 and 94.8 days) to mature in the year 2005 and 2006 respectively, while variety 'CAL 606' matured late (108.2 and 107.7 days) in the year 2005 and 2006 respectively. This could be attributed to their varietal response, since varieties differ in the length of time they may remain at the vegetative stage before bulbs are formed and become matured. Similarly, variety 'Onion Orient' is considered tolerant to harsh weather conditions and could withstand prolonged high temperatures (Ado,

Table1: Meteorological information, Anse Boileau, Seychelles (April-September) 2005, 2006

\begin{tabular}{lcccc}
\hline \multicolumn{1}{c}{ Months } & $\begin{array}{c}\text { Average monthly } \\
\text { rainfall (mm) }\end{array}$ & $\begin{array}{c}\left.\text { Average monthly temperature } \mathbf{~}^{\mathbf{0}} \mathbf{C}\right) \\
\text { Max }\end{array}$ & $\begin{array}{c}\text { Min. } \\
\text { Average relative } \\
\text { humidity (\%) }\end{array}$ \\
\hline $\mathbf{2 0 0 5}$ & & & & \\
April & $7.8(18)^{+}$ & 30.0 & 23.3 & 85.2 \\
May & $8.0(23)$ & 30.2 & 23.2 & 86.0 \\
June & $15.8(25)$ & 30.2 & 23.1 & 85.8 \\
July & $4.2(12)$ & 28.0 & 22.6 & 83.6 \\
August & $3.9(17)$ & 28.5 & 22.4 & 83.5 \\
September & $5.1(16)$ & 29.4 & 23.0 & 80.1 \\
2006 & & & & \\
April & $9.6(20)^{+}$ & 28.2 & 23.4 & 85.0 \\
May & $10.2(22)$ & 29.2 & 23.2 & 85.2 \\
June & $15.3(24)$ & 28.3 & 23.1 & 83.4 \\
July & $4.0(11)$ & 28.4 & 22.8 & 81.4 \\
August & $3.6(17)$ & 27.5 & 22.2 & 81.2 \\
September & $3.8(10)$ & 26.6 & 22.3 & \\
\hline
\end{tabular}

Source: Vegetable Evaluation and Research Meteorological Station, Anse Boileau, Seychelles.

${ }^{+}$Values in parenthesis indicate number of rainy days.

30 Journal of Science and Technology, Vol. 28, No. 3, Dec., 2008 
Table 2: Physico-chemical properties of the soil of experimental site before planting in 2005 and 2006

\begin{tabular}{|c|c|c|c|}
\hline \multirow{2}{*}{ Parameters } & \multicolumn{2}{|c|}{ Soil analytical data } & \multirow{2}{*}{ Method of analysis } \\
\hline & 2005 & 2006 & \\
\hline Organic matter & $1.2 \%$ & $1.4 \%$ & Walkley-Black method \\
\hline Nitrogen & $0.03 \%$ & $0.06 \%$ & Kjeldahl method \\
\hline $\mathrm{P}_{2} \mathrm{O}_{5}$ & $6.2 \mathrm{ppm}$ & $7.5 \mathrm{ppm}$ & Flame photometric \\
\hline $\mathrm{K}$ & $0.06 \%$ & $0.09 \%$ & Oxidation method \\
\hline $\mathrm{Ca}$ & $1.36 \mathrm{meq} / 100 \mathrm{~g}$ & $1.89 \mathrm{meq} / 100 \mathrm{~g}$ & A.A.S. \\
\hline $\mathrm{Mg}$ & $0.86 \mathrm{meq} / 100 \mathrm{~g}$ & $1.00 \mathrm{meq} / 100 \mathrm{~g}$ & A.A.S. \\
\hline $\mathrm{pH}\left(\mathrm{H}_{2} \mathrm{O}\right)$ & 6.5 & 6.9 & $\mathrm{pH}$ meter \\
\hline $\mathrm{pH}\left(\mathrm{Cacl}_{2}\right)$ & 5.0 & 5.4 & $\mathrm{pH}$ meter \\
\hline
\end{tabular}

Type of Soil: Sandy-loam.

Source: Soil Science Laboratory, Grand Anse, Seychelles. ppm: parts per million.

A.A.S.: Atomic Absorption Spectrophotometer.

2001), which was observed during the study period. This could have also influenced its early germination and subsequent early maturity.

Variety 'CAL 606' produced the greatest number of leaves, which was significantly $(\mathrm{P} \leq 0.05)$ increased by $34.6 \%$ and $40.0 \%$ respectively in 2005 and 2006 compared to that obtained from the standard variety 'Red Creole-1'. This could also be linked to its varietal characteristics.

Variety 'CAL 606' produced the greatest bulb size of $31.8 \mathrm{~cm}^{2}$ and $33.4 \mathrm{~cm}^{2}$ in the year 2005 and 2006 respectively. Variety 'CAL 606' (late maturing) could have benefited from the prolonged accumulation of thermal units necessary for sufficient bulb bulking, thus influencing size. This view supports Shanmugasundaram (2001), who reported that late maturing varieties produced bulb with large size.

Similarly, for both years, 'CAL 606' gave the greatest biological bulb weight, economic bulb weight, dry bulb weight and best yield compared to the other varieties.

Its biological bulb weight, economic bulb weight, dry bulb weight and yield were significantly $(\mathrm{P} \leq 0.05)$ higher by $16.8 \%, 28.6 \%, 35.0$ $\%$ and $33.9 \%$ respectively in 2005 and $10.9 \%$,
$23.6 \%, 30.0 \%$ and $28.9 \%$ respectively in 2006 compared to those obtained from the standard variety 'Red Creole-1'. Best (2000), in a similar experiment in Nova Scotia, Canada, reported that 'CAL 606' produced the best yield compared to six other varieties introduced. The yield produced from varieties 'Red Creole-2', 'Lucy 15205 ' and 'Onion Orient' was significantly $(\mathrm{P} \leq 0.05)$ increased by $28.8 \%, 15.1 \%$ and $9.8 \%$ respectively in 2005 and $25.6 \%, 6.2 \%$ and 5.4 $\%$ respectively in 2006 compared to that obtained from the standard variety 'Red Creole-1'. The highest yield was recorded by variety 'CAL 606', followed by 'Red Creole-2', 'Lucy 15205', 'Onion Orient' and 'Red Creole-1' respectively.

\section{CONCLUSION}

From the results obtained, it can be concluded that variety 'CAL 606' performed best and recommended as a potential replacement to the low yielding popular variety 'Red Creole-1' under field conditions in Seychelles. This is associated with a higher number of leaves, bulb size, biological bulb weight, economic bulb weight, dry bulb weight and yield respectively. It is however recommended that further investigation on the yield performance of the varieties be evaluated across different locations with varied ecology in the Seychelles. 


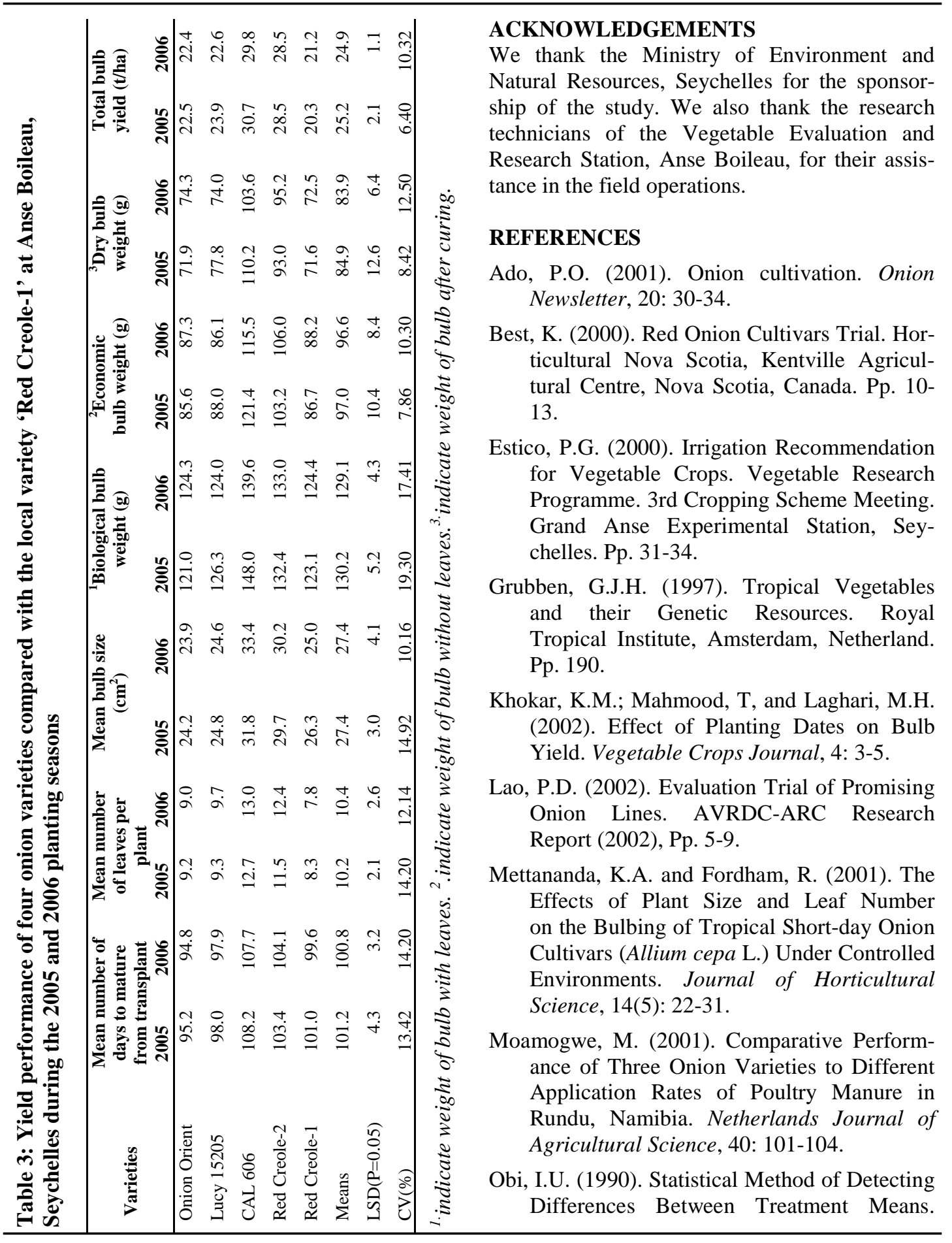

32 Journal of Science and Technology, Vol. 28, No. 3, Dec., 2008 
SNAAP Press (Nig.) Ltd, Enugu, Nigeria. Pp. 1-14.

Ripjma, J. (1990). Fertilizer Recommendation for Seychelles. FAO Fertilizer Report (1990). Pp. 5-7.

Shanmugasundaram, S. (2001). Early Maturing, High and Stable Yielding Onion Lines AVRDC-ARC Research Report (2001). Pp. $10-15$.
Sunasee, S. (2001). Use of Litter for Vegetable Production. Food and Agricultural Research Council, Reduit, Mauritius, Pp. 259-263.

Tindal, H.D. (1983). Vegetable in the Tropics. Macmillan Press, Ltd. London, U.K. Pp. 20-23. 